
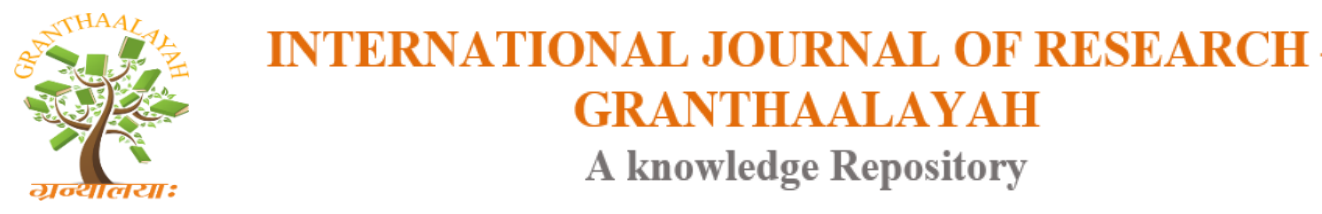

Social

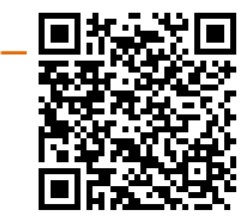

\title{
ROLE OF RELIGIOUS PREACHING IN UPBRINGING OF NEW GENERATION
}

\author{
Dr. Paras Jain ${ }^{1}$, Soman Malaiya ${ }^{2}$, Anupam Jain ${ }^{3}$ \\ ${ }^{1}$ Director, Silicobyte Katni Degree College, Dikshabhumi Campus, Adharkap, Katni, India \\ ${ }^{2}$ Vice Principal, Silicobyte Katni Degree College, Dikshabhumi Campus, Adharkap, Katni \\ (M.P), India \\ ${ }^{3}$ HOM, Silicobyte Katni Degree College, Dikshabhumi Campus, Adharkap, Katni (M.P), India
}

\begin{abstract}
Children are ambassador of new generation. They belong age of adoption and learning. They may be molded in any shape. Aim of religious preaching is enlighten the way of life, to make able children to face challenges, and knowledge of dos and don'ts. It is helpful to develop optimistic attitude and morality. Present study is focused on finding of impact of religious preaching on children gender wise and age group wise.
\end{abstract}

Keywords: Religious; Preaching; Generation.

Cite This Article: Dr. Paras Jain, Soman Malaiya, and Anupam Jain. (2018). "ROLE OF RELIGIOUS PREACHING IN UPBRINGING OF NEW GENERATION." International Journal of Research - Granthaalayah, 6(5), 377-379. 10.29121/granthaalayah.v6.i5.2018.1465.

\section{Introduction}

Religious preaching relates humanity with religion and spirituality. Deeper reflection on religion, belief, and ethics could contribute enormously to the emergence of a society that seeks to embrace difference and is comfortable to celebrate the presence of a variety of religious and other religious systems. Religious preaching for students contributes not only to the personal reflection and development of children and youth, but should also heighten respect for the beliefs of the other and help build a diverse but cohesive society.

For peaceful life we need to raise kindness, happiness and tolerant in kids and making them capable of their own minds about what to believe. We need to develop trust in them to handle things gracefully. Our parents or grandparents were guided by the well-defined teachings of their faith whether it be Buddhism, Hinduism, Judaism, Islam, Sikhism, folk religions, Christianity.

One of the important features of religious preaching is that it helps to understand place of various religions in the society. It helps children to resolve important questions of their own inner self. By listening and responding to stories from religious traditions children assimilate it as part of their 
personal, social and emotional development. Religion is itself an important contributor to life. Religion has far reaching positive results as it teaches equality, co operation, peace, happiness etc. Moreover, belief in god keeps intact society which is helpful in preventing crime and antisocial activities.

\section{Objective}

- Finding of impact of religious preaching on male children.

- Finding of impact of religious preaching on male children.

\section{Hypothesis}

1) There is no significant impact of religious preaching on male children.

2) There is no significant impact of religious preaching on female children.

\section{Methodology}

Descriptive survey method was applied for present study. 300 students of age 8-16 years were randomly selected as sample. It was consists of 50\% male and 50\% female. They were categorized gender wise and age group wise. They were tested using self-prepared questionnaire for morality. They were addressed by religious preaching and after 15 days they were tested again. Collected data was tabulated and comparatively analyzed using mean, standard deviation and value as statistical tools.

\section{Finding and Analysis}

Table 1: Impact of Religious Preaching on Children

\begin{tabular}{|c|c|c|c|c|c|c|}
\hline \multirow[t]{2}{*}{ Gender } & \multirow[t]{2}{*}{ Age Group } & \multicolumn{2}{|c|}{ Before Preaching } & \multicolumn{2}{|c|}{ After Preaching } & \multirow[t]{2}{*}{ t Value } \\
\hline & & Mean & S.D. & Mean & S.D. & \\
\hline \multirow[t]{3}{*}{ Male } & $8-10$ & 21.3 & 1.01 & 28.6 & 0.96 & 0.84 \\
\hline & $11-13$ & 23.6 & 0.97 & 29.7 & 1.03 & 0.81 \\
\hline & 14-16 & 26.8 & 0.92 & 31.3 & 0.91 & 0.89 \\
\hline \multirow[t]{3}{*}{ Female } & $8-10$ & 22.7 & 0.81 & 31.1 & 0.73 & 0.91 \\
\hline & $11-13$ & 24.3 & 0.87 & 30.7 & 0.85 & 0.78 \\
\hline & $14-16$ & 27.4 & 0.79 & 32.1 & 0.82 & 0.83 \\
\hline
\end{tabular}

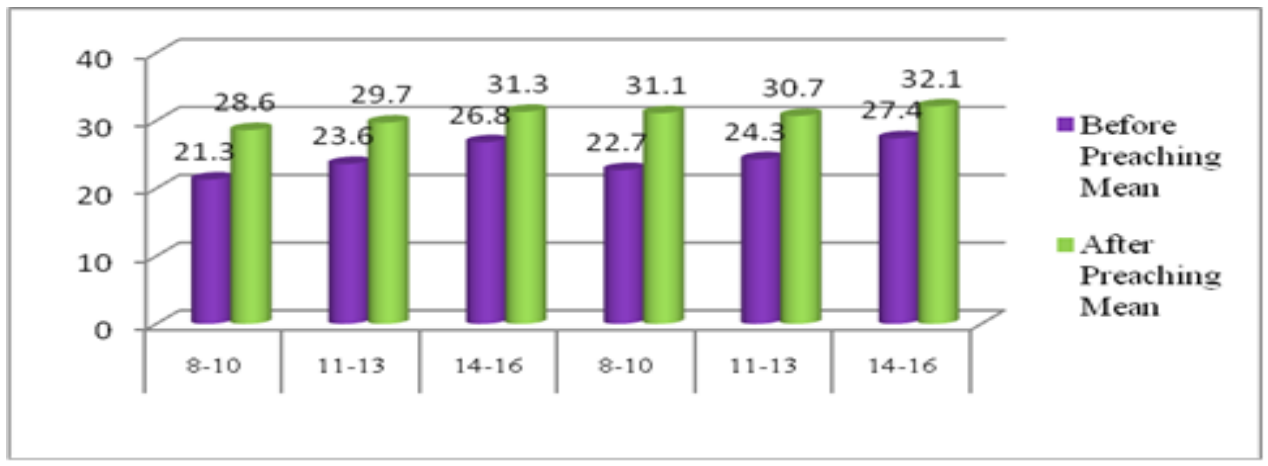


Impact of religious preaching observed among male children of 8-10 years as mean value varies from 21.3 to 28.6 and t value is calculated as 0.84 . Among children of 11-13 years mean value changes from 23.6 to 29.7 with $t$ value 0.81 . For the children of 14-16 years impact mean value reached 31.3 from 26.8 and $t$ value found 0.89 . Thus hypothesis 1 , there is no significant impact of religious preaching on male children is rejected.

Influence on females of age group 8-10 found 22.7 to 31.1, t value as 0.91 . Among age group 1113 years mean value changed from 24.3 to 30.7 with $t$ value 0.78 . Mean value varied from 27.4 to 32.1 and $t$ value as 0.83 for age group 14-16 years female.

\section{Conclusion}

Religious preaching is important for everyone's life. It is practicality of life education which is not written in books. Everyone needs to know the way to live life, inspiration to face challenges. All religions have almost same message and give morality, confidence, happiness and peace. It determines ethics and values in life and has great impact on children. It is beyond the physical things, provides real success to life and creates vision of humanity. To neglect religious preaching is to neglect the reality of life.

\section{References}

[1] Thomas, W., "Relax, It's Just God: How and Why to Talk to Your Kids About Religion When You're Not Religious," comes out today, https://www.pbs.org

[2] Byrne,G., Why religious education has an important role to play in our society, https://www.irishtimes.com, Jul 3, 2014

[3] https://www.pbs.org

[4] www.childrenssermonsonline.net

*Corresponding author.

E-mail address: parasjainkatni@gmail.com 